\title{
TRANSFORMASI NILAI-NILAI BUDAYA LOKAL SEBAGAI UPAYA PEMBANGUNAN KARAKTER BANGSA
}

\author{
Rasid Yunus \\ Staf Pengajar Universitas Gorontalo \\ Email: rasid.yunus@gmail.com
}

\begin{abstract}
ABSTRAK
Penelitian ini dilatarbelakangi oleh keberadaan dan keragaman nilai-nilai budaya yang dimiliki oleh bangsa Indonesia belum optimal dalam upaya pembangunan karakter bangsa. Penelitian ini bertujuan untuk menggali, mengkaji dan memperoleh gambaran secara deskriptif tentang proses transformasi nilai-nilai budaya Huyula sebagai upaya pembangunan karakter bangsa di Kota Gorontalo. Pendekatan penelitian ini adalah kualitatif dengan metode studi kasus. Pengumpulan data melalui observasi, wawancara, dokumentasi dan studi literature. Teknik analisis data meliputi pengumpulan data, reduksi, display dan kesimpulan. Temuan penelitian menunjukan bahwa budaya Huyula mengandung nilai-nilai luhur Pancasila dapat dijadikan sebagai sarana pembangunan karakter bangsa di Kota Gorontalo.
\end{abstract}

Kata Kunci: budaya huyula, karakter bangsa

\section{ABSTRACT}

The Background of the research is being of culture values and its various that have been owned by Indonesia were not optimal in growing effort of the nation character. Meanwhile the purposes of the research are for digging, reciting, and getting a description about the process of the Huyula culture transformation as the growing of nation character in Gorontalo. The approach that is used in the research was qualitative by a case study method. Meanwhile, the compilation of data is gained by observation, documentary interview, and study of literature. Whereas, the technique of analyzing the data such as reduction, display, and conclusion. The invention of the research showed that Huyula culture contains the glorious value of Pancasila that is able to tobe a media in the growing of nation character in Gorontalo.

Keywords: huyula culture, nation's character

\section{PENDAHULUAN}

Pada dasarnya budaya memiliki nilai-nilai yang senantiasa diwariskan, ditafsirkan dan dilaksanakan seiring dengan proses perubahan sosial kemasyarakatan. Pelaksanaan nilai-nilai budaya merupakan bukti legitimasi masyarakat terhadap budaya. Eksistensi budaya dan keragaman nilai-nilai luhur kebudayaan yang dimiliki oleh bangsa Indonesia merupakan sarana dalam membangun karakter warga negara, baik yang berhubungan dengan karakter privat maupun karakter publik.

Menurut Geertz (1992:5) kebudayaan adalah 'pola dari pengertian-pengertian atau makna yang terjalin secara menyeluruh dalam simbol-simbol yang ditransmisikan secara historis, suatu sistem mengenai konsepsi- konsepsi yang diwariskan dalam bentukbentuk simbolik yang dengan cara tersebut manusia berkomunikasi, melestarikan dan mengembangkan pengetahuan dan sikap mereka terhadap kehidupan'. Pendapat ini menekankan bahwa kebudayaan merupakan hasil karya manusia yang dapat mengembangkan sikap mereka terhadap kehidupan dan diwariskan dari satu generasi ke generasi berikutnya melalui proses komunikasi dan belajar agar generasi yang diwariskan memiliki karakter yang tangguh dalam menjalankan kehidupan.

Namun seiring perkembangan zaman, eksistensi budaya dan nilai-nilai budaya yang dimiliki oleh bangsa Indonesia sampai saat ini belum optimal dalam upaya membangun karakter warga negara, bahkan 
setiap saat kita saksikan berbagai macam tindakan masyarakat yang berakibat pada kehancuran suatu bangsa yakni menurunnya perilaku sopan santun, menurunnya perilaku kejujuran, menurunnya rasa kebersamaan, dan menurunnya rasa gotong royong diantara anggota masyarakat. Sehubungan dengan hal tersebut menurut Lickona (1992:32) terdapat 10 tanda dari perilaku manusia yang menunjukan arah kehancuran suatu bangsa yaitu: (1) meningkatnya kekerasan dikalangan remaja; (2) ketidakjujuran yang membudaya; (3) semakin tingginya rasa tidak hormat kepada orang tua, guru dan figur pemimpin; (4) pengaruh peer group terhadap tindakan kekerasan; (5) meningkatnya kecurigaan dan kebencian, (6) penggunaan bahasa yang memburuk; (7) penurunan etos kerja; (8) menurunnya rasa tanggungjawab individu dan warga negara; (9) meningginya perilaku merusak diri; dan (10) semakin kaburnya pedoman moral.

Pembangunankarakterbangsa melaluibudaya lokal sangatlah dibutuhkan. Pembangunan karakter bangsa dapat ditempuh dengan cara mentransformasi nilai-nial budaya lokal sebagai salah satu sarana untuk membangun karakter bangsa. Pentingnya transformasi nilai-nilai budaya lokal sebagai salah satu sarana untuk membangun karakter bangsa adalah sebagai berikut: (1) Secara filosofis, pembangunan karakter bangsa merupakan sebuah kebutuhan asasi dalam proses berbangsa karena hanya bangsa yang memiliki karakter dan jati diri yang kuat yang akan eksis; (2) Secara ideologis, pembangunan karakter merupakan upaya mengejewantahkan ideologi Pancasila dalam kehidupan berbangsa dan bernegara. Secara normatif, pembangunan karakter bangsa merupakan wujud nyata langkah mencapai tujuan negara; (3) Secara historis, pembangunan karakter bangsa merupakan sebuah dinamika inti proses kebangsaan yang terjadi tanpa henti dalam kurun sejarah, baik pada zaman penjajah, maupan pada zaman kemerdekaan; (4) Secara sosiokultural, pembangunan karakter bangsa merupakan suatu keharusan dari suatu bangsa yang multikultural (Desain Induk Pembangunan Karakter Bangsa Tahun 2010-2025:1).

Dalam upaya pembangunan karakter bangsa apabila kurang memperhatikan nilai-nilai budaya bangsa Indonesia maka akan berakibat pada ketidakpastian jati diri bangsa yang menurut Desain Induk Pembangunan Karakter Bangsa Pemerintah Republik Indonesia Tahun 2010-2025 (20102025:2) akan terjadi: (1) disorientasi dan belum dihayati nilai-nilai Pancasila sebagai filosofi dan ideologi bangsa, (2) keterbatasan perangkat kebijakan terpadu dalam mewujudkan nilai-nilai esensi Pancasila, (3) bergesernya nilai etika dalam kehidupan berbangsa dan bernegara, (4) memudarnya kesadaran terhadap nilai-nilai budaya bangsa dan bernegara, (5) ancaman disintegrasi bangsa, dan (6) melemahnya kemandirian bangsa.

Berdasarkan hal tersebut di atas, pembangunan karakter bangsa melibatkan berbagai pihak baik keluarga, lingkungan sekolah, serta masyarakat luas. Pembangunan karakter bangsa tidak akan berhasil selama pihak-pihak yang berkompeten untuk menunjang pembangunan karakter tersebut tidak saling bekerja sama. Oleh karena itu, pembangunan karakter bangsa perlu dilakukan di luar sekolah atau pada masyarakat secara umum sesuai dengan kearifan budaya lokal masing-masing. Hal yang sama disampaikan oleh Eddy (2009:5) bahwa "pelestarian kebudayaan daerah dan pengembangan kebudayaan nasional melalui pendidikan baik pendidikan formal maupun nonformal, dengan mengaktifkan kembali segenap wadah dan kegiatan pendidikan".

Salah satu sarana untuk membangun karakter bangsa dengan cara mentransformasi nilainilai budaya lokal yaitu budaya gotong royong (Huyula) yang dulu dikenal oleh masyarakat Gorontalo sebagai sarana untuk 
bekerja sama dalam menyelesaikan suatu pekerjaan demi kepentingan umum. Huyula merupakan suatu sistem gotong royong atau tolong menolong antara anggota masyarakat untuk memenuhi kebutuhan dan kepentingan bersama yang didasarkan pada solidaritas sosial. Hal ini tercermin dalam kegiatan yang dilaksanakan secara bersama oleh seluruh anggota masyarakat seperti halnya dalam kegiatan kekeluargaan ataupun kegiatan pertanian.

Tetapi, dengan hadirnya globalisasi yang kurang terfilterisasi denganbaikmenyebabkan budaya Huyula sedikit demi sedikit hilang dalam kebiasaan masyarakat Gorontalo. Menurut Laliyo (Mohammad, 2005:366-367) hadirnya globalisasi kearifan lokal Gorontalo semakin termarjinalkan, hal ini nampak pada perilaku masyarakat Gorontalo yang sudah mulai mengabaikan budaya Huyula yang dulu pernah dipraktekkan oleh leluhur.

Berdasarkan kondisi di atas, maka pembangunan karakter bangsa melalui budaya lokal sangatlah penting. Oleh karena itu, penyusun tertarik untuk melakukan kajian tentang penelitian tesis dengan tema transformasi nilai-nilai budaya lokal sebagai upaya pembangunan karakter bangsa (studi kasus budaya Huyula di Kota Gorontalo).

Penelitian ini merupakan sebuah usaha untuk mengkaji dan menemukan formula baru tentang budaya Huyula agar tetap bertahan di tengah-tengah terpaan arus globalisasi dan informasi. Formula yang dimaksudkan adalah mengkondisikan budaya Huyula sesuai dengan konteks kekinian tanpa menghilangkan nilai-nilai yang terkandung didalamnya khususnya Huyula di Kota Gorontalo. Untuk itu, masalah pokok dalam penelitian ini adalah bagaimana proses transformasi nilai-nilai budaya Huyula sebagai upaya pembangunan karakter bangsa di Kota Gorontalo?. Untuk mempermudah penulis dalam penelitian, maka masalah pokok tersebut dijabarkan menjadi sub permasalahan penelitian sebagai berikut: (1) Bagaimana persepsi masyarakat Kota Gorontalo terhadap budaya Huyula kaitannya dengan upaya pembangunan karakter bangsa?; (2) Bagaimana persepsi masyarakat Kota Gorontalo terhadap transformasi nilainilai budaya Huyula sesuai kondisi yang terjadi saat ini jika dikaitkan dengan upaya pembangunan karakter bangsa?; (3) Apa saja faktor-faktor penunjang dan tantangannya dalam proses transformasi nilai-nilai budaya Huyula sebagai upaya pembangunan karakter bangsa di Kota Gorontalo?; (4) Bagaimana dampak dari proses transformasi nilai-nilai budaya Huyula sebagai upaya pembangunan karakter bangsa di Kota Gorontalo; Apa saja kegiatan-kegiatan yang dilaksanakan oleh pihak-pihak yang berkompeten dalam proses transformasi nilai-nilai budaya Huyula sebagai upaya pembangunan karakter bangsa di Kota Gorontalo?

Adapun tujuan penelitian ini untuk: (1) Mengetahui persepsi masyarakat Kota Gorontalo terhadap Huyula kaitannya dengan upaya pembangunan karakter bangsa; (2) Mengetahui persepsi masyarakat Kota Gorontalo terhadap transformasi nilai-nilai budaya Huyula sesuai kondisi yang terjadi saat ini kaitannya dengan upaya pembangunan karakter bangsa; (3) Mengetahui faktorfaktor penunjang dan tantangannya dalam proses transformasi nilai-nilai budaya Huyula sebagai upaya pembangunan karakter bangsa di Kota Gorontalo; (4) Mengetahui dampak dari proses transformasi nilai-nilai budaya Huyula sebagai upaya pembangunan karakter bangsa di Kota Gorontalo; dan (5) Mengetahui kegiatan-kegiatan yang dilaksanakan oleh pihak-pihak yang berkompeten dalam proses transformasi nilai-nilai budaya Huyula sebagai upaya pembangunan karakter bangsa di Kota Gorontalo;

Kajian Pustaka dalam penulisan ini adalah:

\section{Transformasi Nilai}

Transformasi menurut Kuntowijoyo 
(2006:56) adalah konsep ilmiah atau alat analisis untuk memahami dunia. Karena dengan memahami perubahan setidaknya dua kondisi/keadaan yang dapat diketahui yakni keadaan pra perubahan dan keadaan pasca perubahan. Transformasi merupakan usaha yang dilakukan untuk melestarikan budaya lokal agar tetap bertahan dan dapat dinikmati oleh generasi berikutnya agar mereka memiliki karakter yang tangguh sesuai dengan karakter yang disiratkan oleh ideologi Pancasila.

Transformasi merupakan perpindahan atau pergeseran suatu hal ke arah yang lain atau baru tanpa mengubah struktur yang terkandung didalamnya, meskipun dalam bentuknya yang baru telah mengalami perubahan. Kerangka transformasi budaya adalah struktur dan kultur. Sementara itu menurut Capra (Pujileksono, 209:143) transformasi melibatkan perubahan jaringjaring hubungan sosial dan ekologis. Apabila struktur jaring-jaring tersebut diubah, maka akan terdapat didalamnya sebuah transformasi lembaga sosial, nilai-nilai dan pemikiran-pemikiran. Transformasi budaya berkaitan dengan evolusi budaya manusia. Transformasi ini secara tipikal didahului oleh bermacam-macam indikator sosial. Transformasi budaya semacama ini merupakan langkah-langkah esensial dalam perkembangan peradaban. Semua peradaban berjalan melalui kemiripan siklus prosesproses kejadian, pertumbuhan, keutuhan dan integritas.

Berdasarkan uraian di atas, dapatlah disimpulkan bahwa transformasi adalah perpindahan dari satu tempat ke tempat yang lain, dan menyebabkan perubahan pada satu objek yang telah dihinggapi oleh sesuatu tersebut. Jadi transformasi dapat menyebabkan perubahan pada satu objek tertentu. Perubahan tersebut terjadi pula pada masyarakat yang mampu mentransformasi nilai-nilai budaya lokal khususnya budaya Huyula yang berada di Kota Gorontalo sebagai dasar keberhasilan pembangunan karakter bangsa.

Dalam teori moral socialization atau teori moral sosialisasi dari Hoffman (Hakam, 2007:131-132) menguraikan bahwa perkembangan moral mengutamakan pemindahan (transmisi) norma dan nilainilai dari masyarakat kepada anak agar anak tersebut kelak menjadi anggota masyarakat yang memahami nilai dan norma yang terdapat dalam budaya masyarakat. Teori ini menekankan pada nilai dan norma yang tadinya terdapat dalam budaya masyarakat ditransformasikan atau disampaikan kepada masyarakat lain agar masyarakat secara umum memiliki dan memahami nilai-nilai budaya dan dapat dijadikan dasar dalam kehidupan bermasyarakat, berbangsa, dan bernegara.

\section{Budaya Huyula}

Bagi masyarakat Gorontalo tradisi gotong royong dikenal dengan istilah Huyula yang menjadi ciri khas kepribadian masyarakat Gorontalo yang telah dibina secara turun temurun. Dalam Buku Perjuangan Rakyat di Daerah Gorontalo, Menentang Kolonialisme dan Mempertahankan Negara Proklamasi (1982:9) Huyula bagi masyarakat Gorontalo merupakan suatu sistem tolong menolong antara anggota-anggota masyarakat, untuk memenuhi kebutuhan dan kepentingan bersama yang didasarkan pada solidaritas sosial melalui ikatan keluarga tetangga dan kerabat.

Mochtar (Mohammad, 2005:320) mengungkapkan bahwa Huyula adalah 'pernyataan kebersamaan dalam membangun, atau kebiasaan memusyawarahkan setiap kebijakan yang akan diambil yang berhubungan dengan kepentingan dan hajat hidup orang banyak'. Berdasarkan pendapat tersebut Huyula merupakan bentuk musyawarah dalam hal merumuskan kebijakan yang akan menjadi dasar dalam pelaksanaan pembangunan demi kepentingan 
bersama. Hal yang sama diungkapkan oleh Daulima (2004:82) Huyula adalah "melakukan suatu pekerjaan bersama oleh sekelompok orang atau anggota masyarakat dalam arti saling membantu dan timbal balik".

Huyula bagi masyarakat Gorontalo penerapannya dapat dilihat dalam beberapa jenis, yaitu: 1) Ambu merupakan kegiatan tolong menolong untuk kepentingan bersama atau lebih dikenal dengan istilah kerja bakti, misalnya pembuatan jalan desa, tanggul desa, jembatan dan sebagainya. Selain itu, ambu merupakan salah satu cara yang digunakan oleh masyarakat untuk menyelesaikan permasalahan di

\section{Tabel 1.}

Jenis dan nilai yang terkandung dalam Huyula

\begin{tabular}{|c|c|c|}
\hline No Kegiatan Huyula & Maksud & Nilai-nilai \\
\hline 1. $A m b u$ & $\begin{array}{l}\text { Merupakan kegiatan tolong menolong untuk } \\
\text { kepentingan bersama, misalnya pembuatan jalan } \\
\text { desa, tanggul desa, dan jembatan. Selain itu, } A m b u \\
\text { juga digunakan untuk menyelesaikan permasalahan } \\
\text { di masyarakat seperti tauran antara kelompok } \\
\text { pemuda. }\end{array}$ & $\begin{array}{l}\text { Kerja sama, } \\
\text { kebersamaan, } \\
\text { tanggungjawab, } \\
\text { musyawarah, } \\
\text { persatuan, dan } \\
\text { peduli. }\end{array}$ \\
\hline 2. Hileiya & $\begin{array}{l}\text { Merupakan kegiatan tolong menolong secara } \\
\text { spontan yang dianggap kewajiban sebagai anggota } \\
\text { masyarakat, misalnya pertolongan yang diberikan } \\
\text { pada keluarga yang mengalami kedukaan dan } \\
\text { musibah lainnya. }\end{array}$ & $\begin{array}{l}\text { Kebersamaan, } \\
\text { tanggungjawab, } \\
\text { empati, dan } \\
\text { peduli. }\end{array}$ \\
\hline 3. Ti'ayo & $\begin{array}{l}\text { Merupakan kegiatan tolong menolong antara } \\
\text { sekelompok orang untuk mengerjakan pekerjaan } \\
\text { seseorang, contohnya kegiatan pertanian, kegiatan } \\
\text { membangun rumah, dan kegiatan membangun } \\
\text { bantayo (tenda) untuk pesta perkawinan. }\end{array}$ & $\begin{array}{l}\text { Kerja sama, } \\
\text { kebersamaan, } \\
\text { musyawarah, } \\
\text { empati, persatuan, } \\
\text { dan peduli. }\end{array}$ \\
\hline
\end{tabular}

\section{Pembangunan Karakter Bangsa}

Istilah karakter bangsa identik dengan "national character" yang erat kaitnnya dengan masalah kepribadian dalam psikologi sosial (Sapriya, 2008:205). Menurut Desain Induk Pembangunan Karakter Bangsa (2010:7) karakter bangsa adalah:

Kualitas perilaku kolektif kebangsaan yang unik-baik tercermin dalam kesadaran, pemahaman, rasa, karsa, dan masyarakat seperti perkelahian antara warga; 2) Hileiya adalah merupakan kegiatan tolong menolong secara spontan yang dianggap kewajiban sebagai anggota masyarakat, misalnya pertolongan yang diberikan pada keluarga yang mengalami kedukaan dan musibah lainnya; 3) Ti'ayo adalah kegiatan tolong menolong antara sekelompok orang untuk mengerjakan pekerjaan seseorang, contohnya kegiatan pertanian, kegiatan membangun rumah, kegiatan membangun bantayo (tenda) untuk pesta perkawinan.

Adapun jenis dan nilai-nilai yang terkandung dalam budaya Huyula nampak dalam tabel berikut ini: 
digunakan untuk mendeskripsikan ciri-ciri kepribadian yang tetap dan gaya hidup yang khas yang ditemui pada penduduk negara bangsa tertentu. Karena hal ini terkait dengan masalah kepribadian yang merupakan bagian dari aspek kejiwaan maka diakui oleh De Vos bahwa dalam konteks perilaku, karakter bangsa dianggap sebagai istilah yang abstrak yang terikat oleh aspek budaya dan termasuk dalam mekanisme psikologis yang menjadi karakteristik masyarakat tertentu.

Pembangunan karakter bangsa merupakan hal yang sangat penting karena berhubungan dengan proses membina, memperbaiki, dan mewarisi warga negara tentang konsep, perilaku, dan nilai luhur budaya Indonesia yang dijiwai oleh nilai-nilai Pancasila dan UUD 1945 sehingga terinternalisasi dalam diri individu dan terbentuk warga negara yang tangguh, kompetitif, berakhlak mulia, bermoral, berbudi luhur, bertoleran, bergotong royong, berjiwa patriotik, berkembang dinamis, berorientasi ipteks yang semuanya didasari oleh iman dan takwa kepada Tuhan Yang Maha Esa.

\section{METODE PENELITIAN}

Penelitian ini dilakukan di Kota Gorontalo tepatnya di tiga kecamatan masing-masing Kecamatan Kota Selatan, Kecamatan Kota Timur dan Kecamatan Kota Barat. Sumber informan dipilih secara purposif sampling dari berbagai kalangan. Adapun sumber informan terdiri atas: pemerintah kecamatan; budayawan; akademisi dan masyarakat. Masing-masing informan terdiri dari pemerintah kecamatan 3 orang, budayawan 3 orang, akademisi 3 orang dan masyarakat 6 orang.

Penelitian ini menggunakan pendekatan kualitatif, dengan metode studi kasus. Pengumpulan data dan informasi dalam penelitian ini dilakukan dengan berbagai cara dan teknik yang berasal dari berbagai sumber baik manusia maupun non manusia.
Teknik pengumpulan data dan informasi dilakukan melalui observasi, wawancara, studi dokumentasi dan studi literatur. Analisis data mengacu pada langkah-langkah yang dipakai oleh Miles dan Huberman (2007:1619) yang terdiri dari tiga alur kegiatan secara bersamaan, meliputi: pengumpulan data; reduksi data; display dan penarikan kesimpulan/verifikasi. Untuk meningkatkan kemampuan peneliti dalam menilai keakuratan hasil penelitian serta meyakinkan pembaca tentang akurasi penelitian yang dilakukan, maka harus menggunakan beragam strategi dalam melakukan validasi (Creswell, 2010:286). Untuk itu, dalam penelitian ini menggunakan tiga strategi dalam melakukan validasi data yang meliputi pengamatan terus menerus, triangulasi dan diskusi dengan teman sejawat.

\section{HASIL PENELITIAN}

1. Persepsi Masyarakat Kota Gorontalo terhadap Budaya Huyula Kaitannya dengan Upaya Pembanguan Karakter Bangsa

Dalam penelitian ini peneliti menggunakan persepsi menurut Rahmat (Machfiroh, 2011:117) yang dimaknai sebagai 'pengalaman tentang objek, peristiwa, atau hubungan-hubungan yang diperoleh dengan menyimpulkan informasi dan menafsirkan pesan'.

Berdasarkan hasil penelitian persepsi masyarakat Kota Gorontalo terhadap budaya Huyula yaitu Huyula merupakan budaya kerja sama atau gotong royong. Selain itu, Huyula merupakan bentuk kesadaran masyarakat untuk bergotong royong atau bekerja sama demi kepentingan umum. Sedangkan persepsi masyarakat terhadap pembangunan karakter bangsa yakni upaya yang dilakukan untuk menemukan kembali jati diri bangsa. Selain itu, pembangunan karakter bangsa ialah pembangunan karakter yang berbasis budaya lokal melalui pendidikan baik pendidikan formal, nonformal dan informal. 
Persepsi masyarakat Kota Gorontalo terhadap Huyula senada pendapat Mochtar (Mohammad, 2005:320) Huyula adalah 'pernyataan kebersamaan dalam membangun, atau kebiasaan memusyawarahkan setiap kebijakan yang akan diambil yang berhubungan dengan kepentingan dan hajat hidup orang banyak'. Pandangan ini menekankan bahwa Huyula dari segi bahasa bukan hanya berbicara tentang gotong royong tetapi lebih dari itu yakni pada tataran semangat kebersamaan masyarakat untuk membangun kepentingan umum ditempuh melalui musyawarah mufakat yang nantinya akan menjadi kebijakan bersama demi kepentingan bersama.

Huyula merupakan sarana melakukan pekerjaan secara bersama-sama agar pekerjaan terasa ringan. Huyula bukan hanya berlaku pada kepentingan umum tetapi juga berlaku pada kepentingan pribadi, misalnya dalam Huyula pertanian yang bentuk kegiatannya membersihkan lahan, membajak, menanam sampai memanen padi yang dilaksanakan secara bergiliran dan suka rela oleh petani. Hal ini sesuai pernyataan Daulima (2004:82) bahwa Huyula adalah "melakukan suatu pekerjaan secara bersamasama dalam arti saling membantu dan timbal balik".

Kaitannya dengan pembangunan karakter bangsa, budaya lokal merupakan salah satu dasar pembentukan karakter bangsa. Karakter bangsa merupakan sikap dan perilaku warga negara yang sesuai dengan kaidah-kaidah yang berlaku di masyarakat. Kaidah-kaidah tersebut merupakan satu kesatuan yang ada dalam kehidupan masyarakat yang memiliki kekuatan tersendiri dalam menunjang keberhasilan pembangunan karakter bangsa. Karakter bangsa pula yang memberi jalan terhadap keberhasilan suatu bangsa. Karakter bangsa merupakan cerminan perilaku seseorang dalam masyarakat. Pendapat yang sama di sampaikan oleh Sapriya (2008:2005) menurutnya karakter bangsa identik dengan "national character" yang erat kaitannya dengan masalah kepribadian dalam psikologi sosial.
De Vos (Budimansyah dan Suryadi, 2008:77-78) menjelaskan bahwa karakter bangsa yaitu 'the term 'national character' is used describe the enduring personality characteristics and unique life style found among the populations particular nations state' dengan kata lain bahwa karakter bangsa digunakan untuk mendeskripsikan ciri-ciri kepribadian yang tetap dan gaya hidup yang khas yang ditemui pada penduduk negara bangsa tertentu. Karena terkait dengan masalah kepribadian yang merupakan bagian dari aspek kejiwaan maka diakui oleh De Vos bahwa dalam konteks perilaku, karakter bangsa dianggap sebagai istilah yang abstrak yang terikat oleh aspek budaya dan termasuk dalam mekanisme psikologis yang menjadi karakteristik masyarakat tertentu.

2. Persepsi Masyarakat Terhadap Transformasi Nilai-Nilai Budaya Huyula Kaitannya terhadap Upaya Pembangunan Karakter Bangsa

Menurut informan transformasi nilainilai budaya Huyula adalah upaya yang dilakukan oleh pemerintah, masyarakat dan lembaga pendidikan dalam menurunkan atau memindahkan nilai-nilai yang terkandung dalam budaya Huyula ke diri individu atau masyarakat agar masyarakat dapat melaksanakan nilai-nilai kebaikan sebagaimana terkandung dalam Huyula tersebut. Hal ini senada dengan pernyataan Kuntowijoyo. Menurut Kuntowijoyo (2006: 56) transformasi adalah konsep ilmiah atau alat analisis untuk memahami dunia. Karena dengan memahami perubahan setidaknya dua kondisi/keadaan yang dapat diketahui yakni keadaan pra perubahan dan keadaan pasca perubahan. Transformasi merupakan usaha yang dilakukan untuk melestarikan budaya lokal agar budaya lokal tetap bertahan dan dapat dinikmati oleh generasi berikutnya agar mereka memiliki karakter yang tangguh sesuai dengan karakter yang disiratkan oleh ideologi Pancasila. Karakter ini dapat terwujud jika masyarakat terbiasa mentransformasi nilai-nilai yang terdapat 
dalam budaya lokal khususnya budaya Huyula yang berada di Kota Gorontalo.

Transformasi nilai adalah usaha atau kegiatan yang dilakukan untuk tetap melestarikan atau mengembangkan nilai-nilai yang terkandung dalam budaya agar budaya tersebut dapat menjawab kompleksitas permasalahan yang dialami oleh masyarakat. Dengan adanya transformasi nilai ini masyarakat dapat mengetahui nilai-nilai yang menjadi acuan dalam hidup agar mereka dapat menyesuaikan dengan perkembangan yang ada tanpa melupakan nilai-nilai dasar yang terkandung dalam budaya lokalnya.

TransformasinilaimenurutHoffman(Hakam, 2007:156) yaitu proses internalisasi sebagai transisi dari orientasi eksternal ke orientasi internal dalam perkembangan nilai dan moral, internalisasi yang awalnya eksternal atau berdasarkan norma dan nilai budaya masyarakat berarti telah terjadi pergeseran dari orientasi eksternal menuju orientasi diri sendiri dalam memotivasi tindakan seseorang. Sejalan dengan pernyataan ini sebagaimana tedapat dalam teori moral sosialication dari Hoffman (Hakam, 2007:131-132) bahwa perkembangan nilai dan moral mengutamakan pemindahan (transmisi) nilai dan moral dari budaya masyarakat kepada anak agar anak tersebut kelak menjadi anggota masyarakat yang memahami nilai dan norma yang terdapat dalam budaya masyarakat.

Kaitannya dengan penjelasan di atas, maka eksistensi Huyula dan nilai-nilai yang terkandung didalamnya agar dapat menjadi perilaku atau karakter anak atau masyarakat maka langkah yang harus ditempuh adalah mentransformasi nilai-nilai budaya Huyula sesuai dengan kegiatankegiatan yang diperlukan masyarakat dalam konteks kekinian agar budaya Huyula tidak ketinggalan oleh perkembangan zaman.
3. Faktor-Faktor Penunjang dan

Tantangannya dalam Proses

Transformasi Nilai-Nilai Budaya Huyula sebagai Upaya Pembangunan Karakter Bangsa

Berdasarkan hasil penelitian, faktor-faktor penunjang dalam proses transformasi nilai-nilai budaya Huyula sebagai upaya pembagunan karakter bangsa di Kota Gorontalo yakni faktor masyarakat, agama yang dianut yaitu agama Islam, sosial kapital masyarakat dan faktor identitas/ jati diri masyarakat Gorontalo. Sedangkan tantangannya yakni adanya pengaruh globalisasi yang kurang difilter dengan baik, ketidak seriusan masyarakat dalam melestarikan Huyula, kurang efektifnya lembaga pendidikan, dan kurangnya pemahaman pemerintah terhadap Huyula.

a. Faktor Penunjang Proses Transformasi

Faktor penunjang dalam proses transforamsi nilai-nilai budaya Huyula yaitu; Pertama, sosial kapital. Sosial kapital merupakan modal masyarakat Gorontalo yang terbangun dari zaman dahulu sampai sekarang serta memiliki akar sejarah tersendiri bagi masyarakat Gorontalo. Di Gorontalo ada institusi yang dikategorikan sebagai sosial kapital masyarakat dalam melestarikan budaya Huyula. Institusi atau pranata tersebut adalah Bantayo Poboide (Dewan Rakyat). Dulu Bantayo Poboide digunakan sebagai penentu kegiatan-kegiatan masyarakat yang berhubungan dengan budaya, ekonomi, politik, pemerintahan serta sebagai wadah dalam pembuatan aturan tentang adat dan budaya. Sehubungan dengan hal ini menurut Koentjaraningrat (1985:17) dalam aktivitas masyarakat ada pranata yang bertujuan memenuhi kebutuhan manusia untuk mengatur kehidupan berkelompok secara besar-besaran atau kehidupan bernegara, ialah political institusions. Seperti pemerintahan pemerintahan, demokrasi dan sebagainya. 
Sekarang Bantayo Poboide dijadikan sebagai rumah adat berfungsi sebagai simbolisasi adat dan budaya Gorontalo serta sebagai sarana untuk melaksanakan kegiatan adat dan budaya baik yang berhubungan dengan festival kesenian Gorontalo dan pelestarian arsip-arsip budaya Gorontalo serta kegiatan lainnya. Sehubungan dengan hal ini menurut Wulansari (2009:94) fungsi pranata sosial memberikan pedoman pada setiap anggota masyarakat, bagaimana mereka harus berbuat, bertingkah laku atau bersikap dalam menghadapi setiap masalah-masalah yang terdapat di dalam masyarakat terutama yang menyangkut kebutuhan-kebutuhan hidupnya. Artinya walaupun Bantayo Poboide dilihat dari segi fungsinya tidak seperti dulu lagi, namun dalam melaksanakan aktivitas adat dan budaya masyarakat Kota Gorontalo masih menjadikan lembaga ini sebagai sarana pelestarian budaya. Oleh karena itu, eksistensi Bantayo Poboide di Gorontalo merupakan sarana penunjang dalam proses transformasi nilai-nilai budaya agar Huyula masih tetap dipertahankan oleh masyarakat.

Selain adanya Bantayo Poboide, sosial kapital yang dimiliki oleh masyarakat Kota Gorontalo yakni dari segi agama. Masyarakat Kota Gorontalo secara mayoritas pemeluk agama Islam walaupun dari segi ketaatan masih tergolong belum sempurna. Hal yang menarik dalam konteks ini adalah ada satu kebiasaan di masyarakat Gorontalo jika ada anggota masyarakat yang mengalami kedukaan maka anggota masyarakat lain datang ke rumah keluarga yang mengalami kedukaan dengan membawa uang, makanan maupun bantuan lainnya untuk diberikan secara suka rela kepada anggota keluarga yang ditinggalkan dengan harapan untuk mengurangi beban keluarga yang ditinggalkan. Kegiatan ini dikenal dengan sebutan Huyula dalam jenis Hileiya yang dilaksanakan oleh masyarakat yang menganut agama Islam. Hal ini merupakan gambaran bahwa keberadaan pranata sosial sangat berpengaruh pada aktivitas keagamaan masyarakat. Hal yang sama disampaikan oleh Koentjaraningrat
(1985:17) bahwa dalam masyarakat ada pranata yang bertujuan memenuhi kebutuhan manusia untuk berhubungan dengan Tuhan atau dengan alam gaib, ialah religius institusions. seperti tempat-tempat ibadah, doa, kenduri, upacara penyiaran agama dan sebagainya.

Pada saat sekarang Hileiya masih tetap dilaksanakan oleh masyarakat walaupun dalam bentuk pengorganisasian kegiatannya tidak seperti dulu. Di zaman dahulu kegiatan Hileiya dilaksanakan secara spontanitas dan masyarakat langsung datang secara perorangan di rumah kedukaan dengan membawa uang, makanan atau bantuan lainnya. Tapi di era sekarang Hileiya dilaksanakan oleh anggota PKK yang dalam pelaksanaannya, anggota tersebut terkadang tidak menghadiri langsung, dan hanya menitipkan uang atau bantuan lainnya pada anggota PKK yang berkenan hadir pada Hileiya tersebut.

Faktor penunjang kedua, dalam proses transformasi nilai-nilai budaya Huyula yaitu adanya identitas sosial/jati diri. Adapun identitas sosial yang di miliki oleh masyarakat Kota Gorontalo yaitu; (1) terdapatnya satu suku di Gorontalo, kondisi ini mempermudah relasi, komunikasi antara masyarakat yang satu dengan yang lain karena telah terbangun basis kebersamaan kesukuan. Pada level ini proses transformasi nilai-nilai budaya Huyula tidak mendapat hambatan. (2) Gorontalo merupakan daerah pertanian. Dilhat dari mata pencaharian, mayoritas masyarakat Gorontalo adalah petani. Artinya kegiatan Huyula dalam konteks Ti'ayo merupakan satu kebiasaan masyarakat pertanian. Jauh sebelum kebiasaan berhuyula dilaksanakan dalam bentuk Ambu dan Hileiya sesungguhnya pelaksanaan Huyula pertama kalinya dilaksanakan oleh masyarakat pertanian. Mengingat begitu pentingnya pula kebutuhan-kebutuhan lain seperti $\mathrm{Ambu}$ dan Hileiya maka Huyula dilaksanakan dalam kegiatan tersebut. (3) Adanya budaya 
Huyula di Gorontalo. Satu-satunya budaya di Gorontalo khususnya budaya dalam wujud aktivitas masyarakat yaitu budaya Huyula. Hal yang sama disampaikan oleh Daulima (2004:82) bahwa pada sistem ekonomi peninggalan leluhur suku Gorontalo terdapat kegiatan-kegiatan sosial baik yang terkoordinir maupun suka rela. Kegiatan tersebut adalah Huyula.

\section{b. Tantangan dalam Proses Transformasi}

Tantangan dalam proses transformasi nilai-nilai budaya Huyula sebagai upaya pembangunan karakter bangsa di Kota Gorontalo adalah sebagai berikut:

Pertama, adanya pengaruh globalisasi. Globalisasi mempengaruhi hampir seluruh aspek kehidupan masyarakat termasuk dintaranya aspek budaya. Globalisasi sebagai sebuah gejala tersebarnya nilai-nilai dan budaya tertentu ke seluruh dunia. Kontak melalui media menggantikan fisik sebagai sarana utama komunikasi antar bangsa. Kondisi ini mengakibatkan komunikasi antar bangsa lebih mudah dilakukan dan hal ini menyebabkan semakin cepatnya perkembangan globalisasi kebudayaan. Dalam teori dependensi dari Qordoso et al (Syam, 2009-344) bahwa globalisasi dalam arti yang negatif adalah bila yang terjadi bukan heterogenitas melainkan homogenisasi budaya dan gaya hidup dengan menempatkan nilai-nilai universal menjadi tereduksi oleh suatu kepentingan kekuatan dunia yang memang ingin memaksakan kehendaknya. Teori ini mengisyaratkan bahwa globalisasi menyebabkan homogenisasi budaya, dan negara-negara adikuasalah yang memegang kendali kebudayaan di dunia.

Sartini (2004:45) menyatakan bahwa globalisasi sebagai gejala perubahan di masyarakat yang hampir melanda seluruh bangsa sering dianggap ancaman dan tantangan terhadap integritas suatu negara. Dengan demikian, bila suatu negara mempunyai identitas tertentu, dalam hal ini budaya lokal ia tidak mungkin lepas dari pengaruh globalisasi ini sehingga budaya lokal harus tetap hidup dan dapat mengikuti perkembangan zaman.

Faktor kedua, tantangan dalam proses transforamsi nilai-nilai budaya Huyula sebagai upaya pembangunan karakter bangsa di Kota Gorontalo yakni kurangnya pemahaman pemerintah daerah terhadap eksistensi budaya Huyula di Gorontalo. Pembagunan karakter bangsa merupakan upaya yang dilakukan untuk menjadikan warga negara memiliki karakter yang baik. Pembangunan karakter bangsa dapat dilakukan melalui budaya lokal karena karakter yang diperlukan untuk hidup berbangsa dan bernegara sebenarnya terkandung dalam budaya lokal yang dimiliki oleh masing-masaing daerah di Indonesia yang merupakan bentuk kristalisasi dari nilai-nilai Pancasila.

Dalam pembangunan karakter bangsa, peran pemerintah memiliki tempat yang sangat strategis. Oleh karena itu, pemerintah dituntut untuk memahami segala potensi daerah yang dapat menunjang pembangunan karakter bangsa. Tetapi, yang terjadi sekarang ini nampaknya pemerintah kurang memperhatikan potensi-potensi lokal yang dimiliki daerahnya sehingga menyebabkan pembangunan karakter bangsa tidak berjalan dengan baik. Mana mungkin pemerintah dapat melangsungkan pembangunan karakter bangsa sementara potensi-potensi pendukung yang berada di sekitarnya tidak diberdayakan dengan optimal.

4. Dampak dari Proses Transformasi NilaiNilai Budaya Huyula sebagai Upaya Pembangunan Karakter Bangsa

Berdasarkan hasil penelitian di lapangan, para informan menyatakan bahwa dampak yang dapat diperoleh dari proses transformasi nilai-nilai budaya Huyula sebagai upaya pembagunan karakter bangsa di Kota Gorontalo meliputi: dalam kegiatan Ambu, 
yakni tolong menolong untuk kepentingan umum misalnya pembuatan jalan desa/ kelurahan, tanggul, jamban umum serta sebagai sarana dalam penyelesaian antar konflik masyarakat, akan terjalin sifat kerja sama, kebersamaan, tanggung jawab, musyawarah. Dampaknya dapat menjadikan terbiasa bekerja sama, memiliki kepekaan sosial, terbiasa melaksanakan tanggung jawab dalam masyarakat serta terbiasa menyelesaikan konflik di masyarakat.

Selanjutnya kegiatan Hileiya, merupakan kegiatan tolong menolong secara spontan yang dinggap satu kewajiban sebagai anggota masyarakat, misalnya pertolongan yang diberikan pada keluarga yang mengalami kedukaan dan musibah lainnya. Dampak yang dapat diperoleh dari kegiatan ini tercipta rasa kepedulian, merekatkan rasa persatuan dan kesatuan yang dijiwai oleh rasa ketaqwaan terhadap Tuhan yang Maha Esa.

Kemudian, Huyula dalam bentuk Ti'ayo. Kegiatan ini merupakan tolong menolong antara sekelompok orang untuk mengerjakan pekerjaan seseorang, contohnya tolong menolong dalam kegiatan pertanian, membangun rumah dan kegiatan membangun bantayo (tenda) untuk pesta perkawinan. Dampak yang dapat diperoleh yakni masyarakat dapat mengetahui, melaksanakan dan melestarikan budaya Huyula serta menjadikan pekerjaan masyarakat terasa ringan.

Berdasarkan penjelasan tersebut di atas, peneliti menyimpulkan bahwa dampak yang dapat diperoleh dari proses transformasi nilainilai budaya Huyula baik dalam kegaiatan Ambu, Hileiya dan Ti'ayo masyarakat terbiasa melaksanakan nilai-nilai Pancasila yang menjadi dasar utama dalam upaya pembangunan karakter bangsa.

5. Kegiatan-Kegiatan yang dilaksanakan oleh Pihak-Pihak yang Berkompeten dalam Proses Transformasi NilaiNilai Budaya Huyula sebagai Upaya

\section{Pembangunan Karakter Bangsa}

Pada bagian ini akan disajikan kegiatankegiatan yang telah dilaksanakan dalam proses transformasi nilai-nilai budaya Huyula. Sebagian kegiatannya masih seperti dulu, namun sebagian lagi dilaksanakan sesuai dengan konteks kekinian tanpa mengabaikan nilai-nilai yang terkandung dalam Huyula.

a. Kegiatan dalam bentuk Ambu

Di Kota Gorontalo masih menjadikan $\mathrm{Ambu}$ sebagai suatu kewajiban untuk dikerjakan. Tingkat partisipasi masyarakat dalam bekerja bakti untuk mengerjakan sesuatu pekerjaan dapat dikatakan cukup tinggi walaupun dilihat dari tingkat partisipasi masyarakat sekarang ini sudah mulai berkurang.

Di Kecamatan Kota Timur kegiatan kerja bakti diarahkan pada pembersihan selokanselokan air yang dilaksanakan setiap hari jum'at (kegiatan jum'at bersih) oleh pemerintah kecamatan dan masyarakat. Tetapi dalam pelaksanaannya masyarakat kurang melibatkan diri karena terkontaminasi dengan kondisi sekarang bahwa jika bekerja maka ada imbalan atau sewa. Demikian pula di Kecamatan Kota Barat, Ambu termanifestasikan dalam bentuk kerja bakti dan telah dijadikan sebagai suatu kebiasaan untuk membangun kantor kelurahan. Dalam pembangunan kantor kelurahan masyarakat sendiri yang menyumbangkan dana untuk pembelian bahan-bahan bangunan, serta masyarakat bergotong royong menyumbangkan tenaga secara bergantian untuk membangun kantor kelurahan tersebut. Dan di Kecamatan Kota Selatan kegiatan Ambu dilaksanakan dalam bentuk kegiatan kepemudaan yaitu Pemilihan Putra Putri Terbaik tingkat Kota Gorontalo (Pemilihan Nou dan Uti), serta Pemilihan Putra Putri Islam Berprestasi (PPIB).

b. Kegiatan dalam bentuk Hileiya

Hileiya merupakan kegiatan tolong menolong yang diberikan kepada keluarga yang mengalami kedukaan atau musibah lainnya. Bantuan yang diberikan berupa uang, pakaian 
dan benda material lainnya sesuai dengan kebutuhan orang yang terkena musibah serta disesuaikan pula kemampuan masyarakat. Hasil penelitian menunjukan bahwa seluruh kecamatan yang dijadikan lokasi penelitian masih melaksanakan kegiatan ini yang dilaksanakan oleh ibu-ibu PKK, walaupun dilihat dari partisipasi masyarakat mulai berkurang.

\section{c. Kegiatan dalam bentuk Ti'ayo}

Dalam kehidupan masyarakat pertanian, Ti'ayo merupakan suatu sistem pengerahan tanaga tambahan dari luar keluarga untuk mengisi kekurangan tenaga pada masa-masa sibuk dalam lingkaran aktivitas produksi bercocok tanam di sawah. Hasil penelitian menunjukan bahwa kegiatan Ti'ayo masih dilaksanakan di Kota Gorontalo seperti di Kecamatan Kota Timur dan Kecamatan Kota Barat. Namun dalam bentuk pengorganisasian kegiatannya berbeda dengan yang dilakukan sebelumnya. Jika dahulu kegiatan ini dilaksanakan oleh semua petani, namun di era sekarang kegiatan ini dilaksakan melalui kelompok-kelompok tani sehingga ketika ada kegiatan Ti'ayo yang hadir bukan lagi perindividu melainkan perwakilan masingmasing kelompok tani. Selain itu, kelompok tani ini mempermudah Ti'ayo pada era sekarang mulai ditinggalkan oleh masyarakat maupun mempermudah komunikasi jika ada bantuan dari pemerintah baik bantuan pupuk maupun bantuan lainnya. Sehubungan dengan hal ini menurut Koentjaraningrat (1985:16) bahwa dalam kegiatan sosial ada pranata sosial yang berdasarkan kebutuhan hidup dan kesejahteraan manusia yakni economic institusions yang berarti pranata-pranata yang bertujuan memenuhi kebutuhan manusia untuk pencarian hidup, memproduksi, menimbun dan mendistribusi harta dan benda. Contoh yang dilaksanakan oleh pranata ini adalah pertanian, peternakan, perburuan, industri, barter, koperasi, penjualan dan sebagainya.

Berdasarkan penjelasan di atas, peneliti menyimpulkan bahwa kegiatan-kegiatan yang telah dilaksanakan dalam proses transformasi nilai-nilai budaya Huyula meliputi: kegiatan jum'at bersih; membangun kantor kelurahan; Pemilihan Putra Putri Islam Berprestasi (PPIB) tingkat Kota Gorontalo; kegiatan yang dilakukan oleh ibu-ibu PKK terhadap keluarga yang anggota keluarga/masyarakat mengalami kedukaan dan kegiatan gotong royong di sawah yang dilakukan oleh kelompok tani.

\section{KESIMPULAN}

Merujuk pada hasil temuan dan pembahasan, peneliti merumuskan kesimpulan penelitian sebagai berikut:

a. Persepsi masyarakat Kota Gorontalo terhadap Huyula yaitu masyarakat memahami budaya Huyula dan dapat dijadikan sebagai sarana pembangunan karakter bangsa;

b. Masyarakat Kota Gorontalo mempersepsikan transformasi nilai-nilai budaya Huyula merupakan upaya yang dilakukan oleh pemerintah, masyarakat dan lembaga pendidikan untuk menjadikan nilai-nilai budaya Huyula sebagai dasar dalam upaya pembangunan karakter bangsa;

c. Faktor penunjang dan tantangan dalam proses transformasi nilai-nilai budaya Huyula yaitu:

a). Faktor penunjang, yakni sosial kapital yang terdiri dari; (1) adanya Bantayo Poboide (rumah adat), (2) faktor agama. Adanya identitas sosial/jati diri terdiri dari; (1) suku Gorontalo, (2) Gorontalo daerah pertanian, dan (3) budaya Huyula.

b). Tantangan dalam proses transformasi budaya Huyula yakni; (1) pengaruh globalisasi; dan (2) kurangnya pemahaman pemerintah daerah terhadap budaya Huyula di Kota Gorontalo;

d. Dampak dari proses transformasi nilai- 
nilai budaya Huyula di Kota Gorontalo sebagai upaya pembangunan karakter bangsa mencakup:masyarakat terbiasa bermusyawarah, bertanggung jawab, dan memahami budayanya dalam hal pemenuhan kebutuhan hidup berbangsa dan bernegara, memiliki karakter yang peduli terhadap sesama manusia serta taat terhadap ajaran agama, dan melestarikan budaya Huyula, serta menjadikan pekerjaan terasa ringan; dan

e. Kegiatan-kegiatan yang telah dilaksanakan dalam proses transformasi mencakup: jum'at bersih, pemilihan Putra Putri Islam Berprestasi (PPIB), membangun kantor kelurahan, membantu masyarakat yang mengalami musibah dan kegiatan gotong royong di sawah yang dilaksanakan oleh kelompok tani.

\section{DAFTAR PUSTAKA}

Budimansyah, D dan Suryadi, K. (2008). PKn dan Masyarakat Multikultural. Bandung: Sekolah Pascasarjana Program Pendidikan Kewarganegaraan Universitas Pendidikan Indonesia.

Creswell, W.J. (2010). Reseach Design Qualitative and Quantitative Approach. Penerjemah Achmad Fawaid. Yogyakarta: Pustaka Pelajar.

Daulima, F. (2004). Aspek-Aspek Budaya Masyarakat Gorontalo. Banthayo Pobo’ide Limboto: Fitrah

Geertz, C. (1992). Tafsir Kebudayaan (Refleksi Budaya). KANISIUS: Yogyakarta.

Hakam, A.K. (2007). Bunga Rampai Pendidikan Nilai. Bandung: Universitas Pendidikan Indonesia.

Keontjaraningrat. (1985). Kebudayaan Mentalitas dan Pembangunan. Jakarta: Gramedia.

Kuntowijoyo. (2006). Budaya dan Masyarakat (Edisi Paripurna). Yogyakarta: Tiara Wacana.

Lickona, T. (1992). Educating For Character How Our Schools Can Teach Respect and Responsibility. New YorkToronto-London-Sydney-Auckland: Bantam Books.

Miles, M dan Huberman, A.M. (2007). Analisis Data Kualitatif: Buku Sumber Tentang Metode-Metode Baru. Jakarta: Universitas Indonesia Press.

Mohammad, F. et al. (2005). Menggagas Masa Depan Gorontalo. Yogyakarta: HPMIG Press.

Pemerintah Republik Indonesia. (2010). Desain Induk Pembangunan Karakter Bangsa Tahun 2010-2025.

Pujileksono, S. (2009). Antropologi (Edisi Revisi). Malang: UMM Press.

Syam, F. (2009). Renungan BJ. Habibie Membangun Peradaban Indonesia. Jakarta: Gema Insani.

Wulansari, D.C. (2009). Sosiologi Konsep dan Teori. Bandung: Rafika Aditama.

Yayasan 23 Januari 1942. (1982). Perjuangan Rakyat di Daerah Gorontalo, Menentang Kolonialisme dan Mempertahankan Negara Proklamasi. Jakarta: Gobel Dharma Nusantara.

\section{Tesis dan Jurnal}

Eddy. (2009). "Kontinuitas Sejarah dan Pengembangan Kebudayaan Nasional dalam Pembinaan Persatuan dan Kesatuan Bangsa". Jurnal IPS. "vol" 17, (32), 1-6.

Machfiroh, R. (2011). Revitalisasi Karakter Bangsa Melalui Pendidikan Kewarganegaraan dengan Pengembangan Budaya lokal (Studi Kasus Budaya Macapat di Masyarakat Kota Surakarta Jawa Tengah).Tesis Magister pada SPS UPI Bandung: Sekolah Pascasarjana Universitas Pendidikan Indonesia.

Sapriya. (2008). "Perspektif Pemikiran Pakar tentang Pendidikan Kewarganegaraan dalam Pembangunan Karakter Bangsa (Sebuah Kajian Konseptual-Filosofis dalam Pendidikan Kewarganegaraan dalam Konteks Pendidikan IPS". Jurnal Acta Civicus. "Vol" 1, (2).

Sartini. (2004). “Menggali Kearifan Lokal”. Jurnal Filsafat, Jilid 37, (2). 